\title{
PaX digitalis. \\ LIFE IN THE AGE OF DIGITAL HYPER-COMMUNICATION
}

\author{
Pax digitalis. Życie w wieku cyfrowej hiperkomunikacji
}

\begin{abstract}
This article is an attempt to critically analyse discourses and positions on the social impact of accelerating digital development. It outlines trends whose seeds were already sprouting before COVID-19, while others have only been sown by the pandemic. Attention should focus on new directions of thinking in the near future. These are emerging research questions, and answering them requires the acquisition of empirics from which new knowledge will emerge. Vectors of change are generally known, on the basis of which anything can be predicted, but it is not known what their resultant will be, what shape the changes will take, and how to evaluate them. Volatility and acceleration are two megatrends resulting from hyper-communication and the technologisation of life. The publication focuses on certain issues, rather arbitrarily selected, which are related to the functioning of digital technologies in society.
\end{abstract}

Keywords: hyper-communication, technology, digitisation, networks, Internet

Streszczenie: Artykut jest próba krytycznej analizy dyskursów i stanowisk w kwestii społecznych skutków akceleracji rozwoju technologii cyfrowych. Nakreślono w nim tren$d y$, których ziarna kiełkowaty już przed COVID-19, a inne zostaty dopiero posiane przez pandemię. Uwaga powinna się w najbliższym czasie skupić na nowych azymutach myślenia. To sa wytaniajace się pytania badawcze i odpowiedź na nie wymaga pozyskania empirii, na bazie której powstanie nowa wiedza. Ogólnie znane sa wektory zmian, na podstawie których można cokolwiek przewidywać, ale nie wiadomo, jaka będzie ich wypadkowa, jaki kształt zmian i jak je ewaluować. Zmienność i przyspieszenie to dwa megatrendy wynikajace z hiperkomunikacji i technologizacji życia. W publikacji skoncentrowano sie na dość arbitralnie wybranych zagadnieniach zwiazanych $z$ funkcjonowaniem technologii cyfrowych w społeczeństwie.

Słowa kluczowe: hiperkomunikacja, technologie, cyfryzacja, sieci, Internet

1 Dr. habil. Kazimierz Krzysztofek, Professor USWPS - Institute of Social Sciences, SWPS University in Warsaw, e-mail: kkrzysz1@swps.edu.pl, ORCID: 0000-0002-1772-8861 


\section{Introduction}

A digital hyper-communication society is being born before our eyes, which is the synergistic effect of the speed of connections, their massiveness, and the powerful distribution of social relations, especially the mediatized ones. This is significantly transforming social structures, although we still have too little empirical evidence to say what results from the imposition of new info-communication technologies on existing social networks: to what extent these networks will "tame" the new technologies, and to what extent they will be dominated by them.

Speed fills the spirit of the age. It was forced by the need to overcome space. As the speed of information transmission became more and more important in economic transactions, it became more and more important to make data and information transmission independent of the physical movement of people transporting the information or other physical carriers.

There was a long way to achieving hyper-communication. Inventions accelerated communication and the circulation of thoughts. Speech as a developed system of symbolic communication made it possible for people to organise themselves within the range of the voice. The invention of ideographic writing, and later the alphabet, allowed for faster transport of thoughts in larger groups of people; printing allowed for the creation of states and empires, while electronic media gave us the global society.

The news about Columbus setting foot on the island of Hispaniola in 1492 travelled to the royal Wawel Castle for almost two years. Over three centuries later, the information about Napoleon's death on St. Helena Island took two months. In the following decades, the speed of information transfer became the key ingredient of success. The telegraph and, a little later, the telephone became milestones in this acceleration process. Railways, steamships, automobiles, and aeroplanes played a similar role in physical transportation. A cumulative process followed: ever-greater speed forced still greater speed in the next stage.

Exponential progress was made in pursuit of it, bringing with it continuous social change. Change happens faster than reflection about it. The dictatorship of time - chronocracy - enters into an alliance with dromocracy - the dictatorship of speed, and its most important dimension is connectionism - connecting everything with everything. Multiplying mass by speed gives speed-space (l'espace-vitesse), as Paul Virillo proposes to call it. Most information today passes through connected computers - "machines of a thousand 
uses," as Neal Postman calls them, so using them is becoming a skill as basic as literacy in the industrial age.

The cult of speed and the rush of time surround us at every turn. Technologies weave ever denser networks, enforcing ever greater mobility, intensifying communication with one another and amplifying the breakdown of social relations. Thanks to networks, human mobility is less and less dependent on physical mobility. This is why telecommunication systems are growing faster than transportation systems, especially in times of pandemics. A tenfold increase in network density is theoretically a hundredfold increase in intersection (crossing) points. The degree of complication of socio-economic development forces the use of ever-faster tools, without which it is no longer possible to collect, process and use the huge "info mass", to control the information noise with the help of traditional information carriers and communication tools. The human brain is no longer sufficient in its function as a memory capacitor, arithmetic calculator and processor, and the information stored on traditional carriers ("workbook memory") is becoming difficult to operationalise and use effectively as a resource of knowledge and a tool for optimising decisions.

The explosion of communication techniques in recent times must have resulted in an incredible concentration of information, intensifying its transmission on the scale of each society and on a global scale. It is estimated that as a result of technological progress in the last century the speed of information transmission has increased over 100 million times. This is why the view that modern man lives in a world of hyper-communication and total information, which changes his physical and cultural environment, is correct. The pace of change is so enormous that 1 year of the Internet is 7 years of any other medium - radio reached its first 50 million listeners after 38 years, television after 13, computers after 16 . The Internet needed only 4 years.

There is no sector that is changing faster than IT. We consume more and more symbols, and they circulate faster than material goods. Faster and faster search engines bombard us with more and more data and information. And yet something should be said about mobile telephony, which is turning each of us into a global terminal. Smartphones thicken the fabric of connections between people. It seems that we still lack the distance to this most important necessity of our times - "a plug to the world".

The society in the age of hyper-communication is a $24 \mathrm{~h}$ society. Life in it is super interesting for active people: it provides plenty of sensations and 
experiences, thousands of attractions, among which the Internet seems to be sesame. It is a waste of time to sleep. The growing number of information channels creates a situation of hyper-selection for the recipient. Within the few waking hours that he can manage, he receives an unusually large number of offers.

\section{Hyper-communication in the age of the COVID-19 pandemic}

Hyper-communication accelerated long before the pandemic, but in its conditions, it even exploded. As we live "under the occupation" of COVID-19, we must be tempted to take a systematic view of the impact of digital hyper-communication on the shapes of societies. The trends of civilization will depend on the scale reached by the new digital order (or perhaps disorder), which becomes the new social operating system.

Many hypotheses have been formulated in previous studies of the Internet, including that the Internet fosters the deepening of social ties; the ties established through it may be as close as those in the offline world. The Internet is a tool for maintaining weak social bonds that would be broken without its participation. Computer network activity does not replace face-to-face contacts, but more often complements other types of communication. The social isolation of individuals increases with the use of the Internet, or vice versa - the Internet, which promotes individualization, simultaneously increases social activity. In the "alone-together" relationship, the Internet creates new ways of being "together" and being "alone".

The higher the network density, the more - according to the law of the power-law of the distribution of relations - the activities of each user affect the others. This can be reduced to three scenarios: digital technologies a) build "something" over society; b) absorb society; c) are absorbed by society. Over the coming years, and perhaps decades, the social sciences will conduct a great deal of research and analysis in search of an answer to the question: where is the Internet leading us? Depending on how much we know about it, its nature and etiology, we can say how much we know about society, or whatever else we call it. Sociology is faced with the question whether the digital world is a complement to society, a new community, or perhaps a new artificial element, or a New PlaNET that cannot be compared to anything. We do not yet know, but 
we can take comfort in the fact that print has waited several hundred years to become familiar with it, and to realize the magnitude of the institutional, social, economic, political, and cultural - in general, civilizational - change it has brought.

Decades ago, Harold Innis (1951) wrote that in every epoch of human history, society, economy, culture had a communication system based on a dominant medium. In every society there were nodal points where knowledge about economy, culture, politics etc. was accumulated and transmitted. For centuries, such nodes were schools, universities, libraries, church institutions (especially some religious congregations, such as Jesuits, Cistercians, Benedictines), and later mass media (Innis 1951). During a pandemic, the function of such a mega-node is increasingly fulfilled by the Internet, whatever we think of it. Those who exercise control over these nodes also wield power. In mass society, such points were exclusively large hierarchical institutions: national governments, companies, media corporations, etc. However, the Internet, especially the Internet of Things, makes such points diffuse and multiply. As a result, access to any information is easier, asymmetry in information and knowledge is reduced, and hierarchical institutions lose their position of information monopoly.

The sociologist must ask himself what social structure is today and what social groups we are dealing with. The canonical division between "community" and "society" is no longer sufficient. Barry Wellman (2001: 227-252) and Manuel Castells (2011) propose the category of network individualism - the privatisation of socialisation, without which it is impossible to understand the phenomenon of networks. A member of such a community is a part of it, but at the same time an autonomous node (connector), independently managing his relations in the network, in a way privatising the community in which he participates. In this sense, the community appears as an individual, unique network of each netter, within which there is no need for contact between all its members. According to some researchers, network individualism as a new pattern of relations takes its toll in the form of an epidemic of loneliness. Activity in the virtual world can be a compensation for loneliness, but not for everyone, it depends on personality, level of extraversion/introversion, location of control (intraand extraversion). It also depends on the intensity of social relationships. In societies with a relatively low contact level, loneliness is experienced to a lesser extent than in societies with a high contact level. Remote working, teaching and other functions differently in these two types of societies. This 
would require empirical verification of how far these types are ideal and how far they are real.

Of the five main orientations of life activity: expressive, ludic, cognitive, normative and instrumental, network individualism touches the normative one the most; we can speak of normative chaos, privatization of morality, weakening of the controlling functions of groups and social institutions or narcissistic personalism ("look at me"). The technosphere dominates over the logosphere.

In the conditions of the pandemic, the migration of many users' activities to the network is increasing, and this requires us to consider whether network individualism, which is the basis of personalized interpersonal networks, will in the long run ensure the construction of relationships characterized by voluntariness, constant maintenance and confirmation of commitment, and relationships that are a source of positive self-esteem for the individual and enable the satisfaction of the need for affiliation, rootedness and security. It is a kind of individualism that makes the individual an egopolis, puts him/her in the centre of social relations and makes him/her their manager.

Mobile technologies, especially the aforementioned smartphone, have the greatest impact on this. People used to complain that people are addicted to it, that they cannot imagine their existence without it. This is true, but we should also look at it from the other side: a smartphone is today's most important tool for personal logistics and everyday life management. Without it, we are blind, devoid of spatial and temporal coordination. This is accompanied by an autonomous revolution: more and more devices, once programmed, can partially do without humans. Driverless cars come to mind, but this applies to smart machines in general. There is a rapid development of this trend related to the Internet of Things and Industry or Economy 4.0. The conclusion of the pandemic is clear: if people get infected by viruses and we are not able to prevent it - and this is gripping the entire world economy by the throat - then it is necessary to involve machines that are resistant, i.e. to accelerate the automation/robotization of production and services. Hence the growing importance of high-tech companies, netocrats under the sign of GAFA (Google-Amazon-Facebook-Apple). Currently, we are already talking about the "Big Nine," because American corporations have been joined by powerful Chinese corporations, including Tencent, Baidu, Alibaba, Huawei, and WeChat (Webb 2019). Admittedly, machines don't consume, and someone has to consume while production 
is going on, but the tax on robots will fund a universal basic income. In an autonomous factory, there will be - and already is in many places - a handful of people in supervision who, if necessary, will keep a $2 \mathrm{~m}$ gap. Because for a while we will be condemned to a " $2 \mathrm{~m}$ economy".

No social practice taking place in the digital world will ever be the same as in the analogue world. There is a growing number of social activities and events that are digital native - they are purely digital. Without cyberspace, they simply would not exist. The Internet comes to our rescue, though it is subject to a wave of criticism. We used to perceive it as a tool for communication, entertainment, expression, a source of information, knowledge, a space for locating our own resources (knowledge, emotions, etc.) and using the resources placed there by fellow users. Today, it turns out to be something much more - a critical infrastructure, necessary for survival, like water supply networks, sewage systems, electricity. If it were not for the Internet, we would probably have a repeat of Black Thursday (October 24, 1929).

This is certainly the triumph of the virtual: it sustains social and working ties, enables shopping, work through Skype, teleconferencing. Everything possible will be digitized, leading to the hybridization of cyber-physical space. "Living digital" is no longer a matter of choice. Paradoxically, a society encoded (by PINs, logins, access passwords) is at the same time transparent (Brin 1998). Relevant services and also businesses know a lot about it.

Transferring most of the orientation of human activity to the online sphere results in a relative decrease in the scale of direct communication and an increase in the mediation of social relations. The world is becoming one big laboratory where people's activity is quantifiable, correlations unavailable to analysts are captured from data "deposits". Of course, this requires powerful computing power, a quantum computer becomes a necessity to mine and process the growing deposits of data in the digital noosphere. The new wealth of the world is at your fingertips (mouse). The result is an acceleration of processes: man learns everything by himself and/ or with the help of a teacher, but he has to spend a lot of time on it. Millions of machines and computers can be taught in deep learning mode almost instantly thanks to applications and programs, and more and more often they learn on their own (e.g. Google's AlphaGo-Zero algorithm, which defeats the masters of the most intelligent strategy games). This incredibly accelerates the processes of production, exchange, and communication. We are 
entering the age of dromocracy. Thanks to omni-communication, the world has become one big hadron collider, where human and non-human entities are elementary particles and are given a high collision velocity. Michel Houellebeck used this metaphor in his book.

The human gap between the human mind and superintelligence may widen. If it will still pay to invest in humans, it will be in that handful of super-intelligent people who will program and manage intelligent systems. Michael Anissimov (2015), a transhumanist and author of the Accelerating Future blog, believes that radically enhanced human intelligence (IA - Intelligence Amplification) can become much more powerful than artificial intelligence (AI - Artificial Intelligence). The realistic goal of human intelligence amplification will be to create not Einsteins, but super-Einsteins - people much sharper than any human living on Earth so far, able to control even the most intelligent machines. Not necessarily. With the advent of artificial intelligence, people will have to move from biological thinking to hybrid thinking - as Ray Kurzweil calls it. One that will combine the potential of man and machine, brain and processor, protein and silicon.

Digital users can wander around a field supervised by algorithms without being able to step outside it. It will not pay to invest in the "man in the street," because investing in artificial intelligence will bring better results. Yuval Noah Harari pessimistically predicts that the governments will not be particularly interested in taking care of the health and mental condition of the masses, because they will not be needed as producers or, for example, soldiers; robots, both "embodied" and purely software ones, will take care of production and warfare. Disbelief in human capabilities will translate into delegating norms of behaviour to machines and engineering solutions. This is not new: for decades, "sleeping policemen" on the streets have been enforcing compliance with vehicle speed limits.

The expanding Internet is the new universe. The Big Bang is underway. For decades, perhaps centuries, man has dreamt of settling alien planets. It hasn't come true so far, but the dream of emigrating to PlaNET Internet is coming true before our eyes. Algorithms penetrate all crevices of life. When sensory feedback appears, the possibility to touch, smell, taste (Stawska 2021), to feel digitally created entities, will complete the digitization of everything that is possible, the hybridization of space. The Internet will be the Omninet; not everything will be digitized, of course, but almost everything that exists physically will have a digital representation. 
"Virtual" and "real" are not two parallel worlds, two separate realities, but one, hybrid, cyber-physical reality. The growing migration of human activities to the web has become a necessity. Even before COVID-19, living in the digital world was not a matter of choice, and today it is a necessity in two ways. A pandemic is forcing its way into cyberspace, you have to log in everywhere, and even if many people resist it, digitization still has a huge impact on their lives as more and more goods and services come in exclusively digital form. Algorithms have taken over, as Lev Manovich put it in the title of his book: Software takes command (Manovich 2013). This has a political dimension. ${ }^{2}$

What is emerging is the conviction of people in politics, business and data scientists that most social problems can be solved with the help of modern technologies, which Evgeni Morozov calls solutionism and which is supposed to mean a kind of laboratoryization of society (Morozov 2013). According to this columnist, solutionism appears to be not so much a social system as a sociotechnical system in which the key to everything is the right number of clicks. This phenomenon fits into the logic of the development of Western civilization since the industrialist phase. The temptation to use science and technology for social engineering has existed since the beginning of the machine age. It was to provide predictability and control over social practices and processes, to restrain their spontaneous and potentially destructive nature.

What are the implications of this? First of all, that the pandemic has accelerated the transition from the old industrial operating system to a new, digital one (Rainie, Wellman 2012). This is the new code in which humans and non-human entities communicate. It is a digital language: in a dozen years, it has brought new phenomena that did not exist 30 years ago. Their names are indicators of changes in the lives of people and societies. For example: chatting, updating, Googling, blogging, cyber-dating, tweeting, and sharing.

Every social order is a kind of operating system. The stakes are high control over the new system. Of course, it will be exercised by the owners

2 Too little attention is paid, for example, to the political potential of Twitter, through which those in power can make a huge difference for the better and for the worse. As Łukasz Walewski aptly observes: impulsively, without advisors, not always soberly. This is how the rulers of nuclear empires, headed by Donald Trump, communicate with the world via Twitter. A single entry over morning coffee can lead to a serious international crisis. And all this in 280 characters (Zalewski 2020). 
of the algorithms. It is the transfer of the logic of the Internet to the whole society, the imposition of new digital infrastructure on the existing social system shaped by the institutions of modern industrial society. The New Social Operating System (hereafter: NSSO), as Rainie and Wellman define it, is software that already manages almost the entire society, creating an environment for triggering, controlling, and managing people's actions. The driving forces behind NSSO are Broadband Internet, including the Internet of Things, social networking and mobile devices, Big Data, and others.

Institutional change processes are taking place: the disappearance of some institutions, the persistence of "Zombie" type institutions, the transformation of others, and the emergence of new ones. In a society regulated by a digital operating system, well-known sociological categories behave differently: power, status (different status characteristics in the virtual than in the real), leadership, ties, groups, references, significant others, exclusion, etc. Sharing analyzed from this perspective is part of a broader process that began with sharing culture thanks to the emergence of online communication platforms, and extends to other spheres: energy production, logistics, education, work, and others. In short, NSSO is a digital overlay on the social system, mediating through it the exchange (acquisition, disposal, free provision) of immaterial goods and services, but also providing platforms that mediate the exchange of material goods and services.

For the most part, these practices are not sharing, but a business model based on online platforms that did not produce anything, but only mediated, like Uber, Airbnb, Netflix, and many others (this is now changing: platforms are becoming producers). At the same time, we have authentic sharing in the form of self-supply of cognitive, informational, ludic, etc., happening outside of corporations and the market. NSSO gives power especially to "network natives" characterized by high networking skills. Most are users operating and developing intellectually within algorithms. This is a group that includes masses of ordinary users who do not have much power, but who are convinced that thanks to mobile technologies they have power, and in a sense, they are right - because through them the power of hyper-communication is revealed. The sense of the subjectivity of the individual user in the network is growing. Corporations are giving users "free" access to collaborative and sharing technologies, thereby gaining deposits of data, content, relationships, and more. This is the currency that users pay. 
NSSO holds much promise, but also raises issues of private ownership of its infrastructure. The evolution of NSSO and the Internet, on whose substrate the system was created, follows the path of earlier technologies: printing, telecommunications, electronic media, which at first operated in a dispersed, pluralistic market, but with time came under the control of corporations concentrating them, as well as government regulations. The Internet, though born as a U.S. government project, depends on business even more than earlier technologies because it has the largest share of the pool. U.S. Internet researcher Tim Wu (2011) fears that it is the corporate-netocracies that have the master switch - the Master Switch - in their hands to turn it off. While this seems unrealistic, as it would be suicidal for them, they do have this ability, to at least partially disable network elements and exclude users (which can be considered a digital form of banishment). This is a broader problem of control over networks. When they didn't exist, everyone had power over tools, their own "comfort", a kerosene lamp, access to water (well). Fragments of the network can be turned off; previously this could be done locally, now it is possible on a global scale. There is more and more talk about technological sovereignty, meaning that one should rely as much as possible on one's own hardware and software, which are not "black boxes" that may have some vulnerabilities sewn into them. It's about controlling the technologies, protecting the data from being hijacked. It's becoming as important as making sure your electricity doesn't get cut off.

What we call society, when combined with technologies, appears as a social machine - a system that involves human and digital subsystems operating automatically (Shadbolt 2013: 200-205; Smart, Shadbolt 2014). It is an artificial, consciously designed, and constructed system of roles and relations that functions in a predictable, regular manner, which is not the result of spontaneous processes and has no counterparts in the existing social reality (Afeltowicz, Pietrowicz 2013). In this sense, social machines are Google, Amazon, Facebook, and others. They are broadly defined as media used to create relationships between people and between people and things.

An experiment created in the People's Republic of China can be included in this genre. It involves not coercion but stimulating loyalty or even obedience to authority by participating in a game that rewards. This has been called social credit (for more see Sesame Credit 2016; Krzysztofek 2018: 73-110), and the idea is to achieve a score that is an indicator of a 'good 
citizen'. Such a citizen is behaviourally controlled, gratified by boons influenced by power, and these are considerable. To stimulate appropriate behaviour, there are of course not only rewards but also punishments, e.g. for maintaining undesirable contacts with "inferior" citizens (low-ranking), or - which would be even more reprehensible - with dissidents, or merely seeking information about such people. There is a certain calculation in it - counting on civic pedagogy: exerting influence by "better" citizens on "worse" ones so that the latter does not "break the streak" and lower the score of the latter.

The question is whether the Chinese model - effective authoritarianism - is not more attractive to the world under threat conditions than the Western, liberal model. Authoritarianism has the advantage of centralizing big data and responding quickly to threats. The risk, of course, is that it is more prone to paralysis when some element of it fails. Much depends on who wins the 5G war. In China's version, the 5.0 society is, as Kai Strittmatter, an expert on the Middle Kingdom, succinctly puts it, a catapult for the economy plus control and self-surveillance, turbocharging, and brain scanning to the last neuron (Strittmatter 2020). The 5G war is also about whose servers should host user data, which is the currency of the 21st century. In the competition for the upper hand in the value chain - higher up in the value chain is the digital - a wave of innovation is likely to emerge, some of which may be disruptive. America is not lost, it has its quartet of data corporations - GAFA, although as mentioned, they are threatened by the expansion of Chinese technology corporations. ${ }^{3}$

China's surveillance system reveals a new truth about the society in the age of digitalization. For most of history, the central government could not get to know the citizen (formerly subject) more closely simply because it could not collect and process much data and information about them. There were people, knowing us very well, but they were usually those whose interests coincided with ours. Now we're getting to the point where some system operating far away from us can know us better than our loved ones or even ourselves, even though our interests don't necessarily

3 But it is an American company, Elon Musk's SpaceX, that is building Starlink - a telecommunications satellite system that will eventually consist of about 12,000 satellites placed in low Earth orbit at 3 altitudes - 340, 550 and $1150 \mathrm{~km}$ above the Earth. It is expected that this system, which will be the substrate for a new generation of the Internet, will increase the intellectual potential of mankind by leaps and bounds (Space Internet coming ever closer to 2020). 
coincide. This is a kind of power that has never existed before, enabling totalitarian and authoritarian regimes to do things previously simply technically impossible. For thousands of years, humans have viewed life as a drama of decision-making. Some of these involve minor matters, such as what to eat for breakfast, and others are major, such as what partner to get involved with - now we are being catered to through algorithms and we like it (Sumpter 2019). It is estimated that in the next 2 years $50 \%$ of decisions will be made by algorithms. Culture, therefore, is no longer just a set of values and norms, but algorithms with norms sewn into them that regulate human behaviour (Domingos 2017).

We are entering the era of digital governance. Gamification, the hunger for instant gratification, the control of people by behavioural reinforcements, the deficit of internal stimulation and the excess of external stimulation (overstimulation), the constant search for stimulation (sensation-seeking behaviour), the "thirst for desire," called hedonic direction, allow the system to draw strength from the self-monitoring/self-surveillance of citizens and consumers, who become the guardians of themselves. This self-monitoring is the "quantified ego" (quantified self, lifelogging), life under the supervision of a chip. Increasingly cheaper technologies, fixed and mobile, allow everyone to monitor themselves: savings, own resources, health, deskilling, and more. The fear of losing their health, competence, and knowledge leads people to supply themselves with these devices, personalize and adapt them (Attali 2008). Self-surveillance becomes a lifestyle as a model of the need for achievement of those who want to participate in this system and let themselves be measured on a single scale - productivity and loyalty while providing gigabytes of data about themselves. As a result, we know less about ourselves - because it escapes our awareness and memory than those who obtain this data, aggregate it into appropriate personality profiles, and often trade it beyond our knowledge and consent. The transfer of valuable data has been going on for a long time and is accelerating. The 1000memories.com portal estimated what part of the data and information about themselves Americans leave on the Internet: in the case of 65 -year-olds it is only $12 \%$, but 45 -year-olds have already deposited $56 \%$ of data about themselves on the Internet, 25 -year-olds - 72\%, and teenagers $-86 \%$. With such a pool of data about a person, a "digital twin" can be created. This will avatarize relationships by creating digital copies of users to replace human actors in transactions of all kinds. 
There are fears that if human development does not accompany the development of technology, it will become an increasingly autonomous system whose actions are determined neither exclusively nor primarily by human needs and characteristics. In the majority of cases the contemporary "man in the street" does not understand the technologies he uses; they are these Foucaultian "black boxes" that prolong or strengthen certain functions of his brain and change his consciousness more and more. Freed from man's control, the development of technology sets before him goals that are not so much the goals of the person, but of the man-machine system, or the man-technology system (Bobryk 2014). The American philosopher and computer scientist Eben Moglen announces the birth of machina universalis, which knows everything about us, tells us how to live, and predicts our good and bad deeds (Moglen 2013). The shape of future societies will depend on what we allow information and communication technologies to do, that is, in essence, on social culture (e.g. we allow less and less use of televisions, getting rid of them from our homes is a trend). We accept those technologies that we are convinced make our lives easier.

Won't the digital age cause technology fatigue by over-technologizing our lives? Already a dozen years ago, a study in Japan showed fear of human-like robots, even though the Japanese were positively disposed towards them. But when robots saturated with machine intelligence relieved people of more and more tasks, including mental ones, anxiety arose: who am I as a person, how am I different from a robot? The engineer and designer of robots, Masahiro Mori, called this the "uncanny valley" (Uncanny valley, presumably in reference to Silicon Valley) (Masahiro 2012). These fears will define the limits of automation in the future. In an automated hospital in Wuhan, reducing the risk of infection for medical staff, patients crave contact with a live nurse or doctor, as the lack of human touch creates a sense of deprivation. This may mean that the machine service will be cheaper, but patients, or users of vending machines in general, will prefer to pay extra to be served at least in part by humans. This is a question not only of comfort and a sense of security but also of social status. 


\section{Conclusions}

Does it have good sides? It depends on how to look at it: multiplication of activities in both spaces - physical and digital, acceleration of the rhythm of life fills the vacuum of existence, a man does not ask himself "stupid" questions about the meaning of life. The nature of info-tech is, on the one hand, an increment of freedom, but on the other, control, speed and power - features that are not friendly to ordinary people and to which it is not easy to adapt. Emphasis on constant acquisition of new skills and competencies, i.e. expansion of human capital, increases the pain of adaptation.

After the invention and spread of printing, politics, economics, culture, and all other areas of life had a few centuries of peace and quiet, which they used to develop education, democracy, etc. Now they have no such comfort; regulatory systems are always one phase behind. Today, speed and control of access is more important than control of space by politics. Technology doesn't have time to improve either.

One of the strategies is to face challenges, actively adapt, chase news, invest in oneself, constantly self-update consuming a lot of time and energy to keep up; to be on course, to be "the best". Other things, such as starting a family, are put aside. If there is a need to increase the efficiency of the body, one does not avoid "tweaking" the psyche. Suitable trainings and specific substances are in abundance. You need to speed along a highway from which there are no exits.

Another vision is to be carried away by the wave; to enjoy the pleasures offered by technology, to immerse oneself in entertainment, games, to live for the moment, to experience something all the time. This is escapism; an escape from the effort of facing challenges, indulging in whims and urges.

The third concept is the attempt to truly escape, to seek an alternative, to not give in to a system in which a person is like a brick-built into that system - if it crumbles, it must be quickly replaced, expelled into the environment. There are many signs that such escapes are becoming more frequent. There is a limit to adaptation somewhere. At this speed, can one be active for a long time, will people adapt to the terror of competence unimaginable one generation back? At some point, the extensions of our senses and minds make us networked products, travelling back and forth.

This raises the question of the subject in a situation where it has no fixed meanings and everything is negotiable. What happens to it in the network that intensifies social relations, in this real virtuality characterized 
by the lack of center, relativity of everything, plurality of truths, illusion, spectacle built into the culture, reproduction, and consumption, blurring in mobility and hyper-communication? Does such a subject disappear or is it merely transformed into some other? Which one? Hovering over everything is the imperative of this hyper-communication, which does extraordinary things to everything.

The future will make this even more complicated, with next-generation network technologies (5G) contributing to this. Japan announced a few years ago the construction of a 5.0 society based on these technologies. These are no longer just cellular networks for mainly interpersonal communication, but also all-encompassing communication between human and non-human (object) actors, as well as between objects (Internet of Things). 5G is expected to solve many problems related to the ageing population, among others. Network technologies of this generation will be the basis of the industries of the future (Ross 2017).

Proponents of 5.0 argue that the difference lies in the human condition. In the information society, it was (indeed, still is) common practice for people to obtain data via networks and process them with IT tools, analysing, interpreting, distilling, contextualising, aggregating, i.e. transforming data into information and integrating it with already possessed knowledge. In society 5.0 people, things, systems, nature are connected in cyberspace and obtain optimal results thanks to artificial intelligence, its analytical potential unavailable to humans. After AI acquires, processes and analyzes data from the physical world in the cloud, it returns to the world of matter, setting autonomous devices, vehicles, bots and more into motion. Machines communicating with each other as part of the Internet of Things is the foundation of Industry 4.0 in This brings previously unattainable new value to the economy and society. In factories that are on the path of transitioning to digital manufacturing - technology productivity is growing at an average of $5 \%$ per year. It is expected that within the next decade, most manufacturing will be able to run $24 / 7$. This will lead directly to dramatic increases in the efficiency of machines, systems and resources, as well as the management of production, scheduling of technological changes, etc. ${ }^{4}$

4 Hopes are pinned on blockchain technologies. This is related to the development of cloud services. A client "suspends" a task in it, and a professional retrieves it from there, solves it and gets paid through it. It is estimated that eventually there will be about 500 million professionals - freelancers - on blockchains, which will fundamentally 
This will change the perception of the profession - it will be a demand not so much for new occupations, but for bundles of new competencies.

SARS-CoV-2 has proven to be a powerful accelerator of technology development. It accelerates processes that would have developed more slowly without it: remote work and education, e-services, e-commerce, e-banking and others. In some areas of digital services, their dynamics, which before the pandemic were estimated to last for years, were recorded in just a few days or weeks. According to the data, web traffic in Europe had already grown by $30 \%$ at the start of the pandemic compared to the same period in 2019. A twofold increase was recorded in the area of traffic generated by gaming and video conferencing software. The number of messages sent via WhatsApp, in turn, increased as much as four times (Olanicki 2020). With these dynamics, it is only a matter of time before the Internet-based on previous generations of network technologies ( $3 \mathrm{G}$ and $4 \mathrm{G}$ ) becomes overloaded. The only salvation is therefore the next generation networks (5G). Sceptics have to answer the question: do we accept the paralysis of networks or do we accept the challenges and problems associated with this new generation (e.g. increase of electromagnetic radiation, which scares users). The key issue seems to be the adaptation of recipients to the requirements of this technology. It should be proactive, anticipatory (anticipatory educational programs in schools, training, courses and others) and not reactive - "taking by surprise" causing stress, etc. The latter directs a person's energy not to personal expansion but to the survival of self and loved ones, that is, it focuses attention on the lower levels of Maslow's hierarchy.

So what about this highly technologized civilization of ours? For a long time, it has been sending out contradictory signals. On the one hand - and this is a truism that has long been discovered - technologies solve many problems, but at the same time, they create new ones, ones that would not exist without the spread of technology. This was pointed out eight years ago by Bill Davidow, who in his book Overconnected. Threats and promise of the Internet (2012), who wrote that due to hyper-communication, i.e. the massive distribution of interactions, networks accelerate everything, for better and for worse - this is their Janus' face. They accelerate crises, they globalize them. B. Davidow attributed the proliferation of crises in the financial 
markets in 2008 to the network technologies that make everything connectable. Because of the density of connections, the world has become viral it is characterized by a logic of contagion, like viruses spreading memes, factoids and almost everything else. Epidemic, infection apart from their medical meaning has always been a metaphor for the spread of social and cultural patterns. Malcolm Gladwell called the critical point from which such an infection becomes dynamic a tipping point. It's not just about computer networks, but all other networks, including transportation networks - of people and things, which, as a result of this powerful distribution of interactions, can transmit the coronavirus exponentially, infecting almost the entire planet in a short period of time. Such is the power of the network multiplier. So far, technologies, including medicine, can't cope with it. Neither can the artificial intelligence we so believe in. There was hope that Google Flu Trends would alert us to every new flu outbreak. However, it turned out to be a false hope.

Technology will cease to be a tool, it will become a part of the techno human system, which has value only as a whole, each of the subsystems alone will be worthless. This will require better and better interfaces for the human-machine ("cephalocomputer"). It will then make no sense to say that a digital device is a tool for man; man himself will in a way become a meta-tool - a tool for a tool.

In order to slow down, civilization must create some kind of antibodies; culture must tame every new change, constantly adjusting to rapidly ageing technologies. I don't think it's possible to slow down anymore. One of the reasons is the Web. Its development has its own logic, which inevitably leads to the total technicization of the world. In effect, man becomes an element of the system, a node of a total network that reduces him to a zoon technon, a technical animal. The connections between its nodes thicken at an ever-increasing pace, eventually suffocating modern civilization in a death grip. In other words, "The Matrix is us."

The turbulent history of technology has always proved the enormous adaptability of man. He has been able to adapt, though not without social harm (anomie, among others), to the production line. The question is whether these psychophysical abilities will allow him to adapt to hyper-communication in this way. Opportunities are seen in the fact that the "analogue generations" are dying out, and digital generations are coming into the picture - "computer children and networked citizens," future-oriented, with a radar personality that directs us to where the strongest 
information impulses come from at any given moment, and they come from cyberspace. But what will happen when you can't go any faster, because your physiology and psyche won't allow it? What direction will man turn, what previously unknown powers will he reach for?

One hears opinions that in the system of man-technology man becomes the weaker link. This gives rise to a dilemma: if people today stand in the way of increasing computer efficiency, what to do: leave them alone and improve technologies that will replace them, or improve man himself so that he does not fall behind as an inferior subsystem in a duet with technology.

This is not a new trend, but such a large scale of mediation of relations as we are dealing with today is unprecedented. The future will tell what direction this civilization trend will take. I don't think anyone has measured it, but it can be assumed that mediatization has outgrown the scale of faceto-face interactions if we take into account non-family relationships. Such communication in the situation of limited contacts in the physical world plays an important therapeutic role, it satisfies the need to be in a community. It is expressed in virtual flocking. It is not the same, of course, but it works as a substitute. Zoon politicon has become $e$-zoon technicon.

According to some researchers, sustained technological development will lead to the fact that in the future, the dominant form of interpersonal contact will not be virtual herding, but the aforementioned network individualism. The hypermedia - the computer and any other networked device - will lead to this. For a few billion people (there are about 6 billion cellphone/smartphone users on the planet), it is already the most important tool, for which it is difficult to find a precedent in the history of technical civilization. Everyone can make their own use of such a tool, create a personal, unique world,"put it through" their own mental and cultural filter, create private representations through which individuals organize the world around them and give it meanings; in a word: personalize it, which was not possible in the era of machines that algorithmized their use by people. 


\section{References}

Afeltowicz, Ł., K. Pietrowicz (2013), Maszyny społeczne. Wszystko ujdzie, o ile działa, (Warszawa: Wydawnictwo Naukowe PWN).

Anissimov, M.M. (2015), Our Accelerating Future. How Superintelligence, Nanotechnology, and Transhumanism Will Transform the Planet, (Duluth: Zenith Books).

Attali, J. (2008), Krótka historia przyszłości, (Warszawa: Prószyński i S-ka).

Bobryk, J. (2014), Transhumanizm, "cognitive science" $i$ wyzwania dla nauk społecznych, "Studia Socjologiczne" 3: 9-27.

Brin, D. (1998), The Transparent Society. Will Technology Force Us To Choose Between Privacy And Freedom? (New York: Perseus Books).

Castells, M. (2011), Społeczeństwo sieci, (Warszawa: Wydawnictwo Naukowe PWN).

Davidow, W.H. (2012), Overconnected. Threats and promise of the Internet, (Santa Monica: Delphinium Books).

Domingos, P. (2017), The Master Algorithm. How the Quest for the Ultimate Learning Machine Will Remake Our World, (London: Penguin Books).

Innis, H. (1951), The Bias of Communication, (Toronto: University of Toronto Press).

Kosmiczny internet coraz blizej. Na orbite dostarczono kolejne satelity Starlink od SpaceX (2020), https://biznes.wprost.pl/technologie/internet/10351081/kosmiczny-internet-coraz-blizej-na-orbite-dostarczono-kolejne-satelity-starlinkod-spacex.html (7.08.2020).

Krzysztofek, K. (2018), Digital Power. Zmieniające się relacje siły w społeczeństwie danych-informacji-wiedzy, [w:] L. Zacher (red.), Potencjaty i relacje sit w cyfrowym społeczeństwie wiedzy, (Warszawa: Wydawnictwo Poltext):73-110.

Manovich, L. (2013), Software takes command, (New York: Bloomsbury Acadamic).

Masahiro, M. (2012), The Uncanny Valley: The Original Essay by Masahiro Mori, http:/ / spectrum.ieee.org/automaton/robotics/humanoids/the-uncanny-valley (7.04.2017).

Moglen, E. (2013), Wolność w chmurze i inne eseje, (Warszawa: Fundacja Nowoczesna Polska).

Morozov, E. (2013), To Save Everything, Click Here. Technology, Solutionism, and the Urge to Fix Problems that Don't Exist, (London: Allen Lane).

Rainie, L., B. Wellman (2012), Networked. The New Social Operating System, (Cambridge: MIT Press).

Ross, A. (2017), Industries of the Future, (London: Simon \& Shuster).

Sesame Credit. Data-Driven Credit Scoring (2016), http:/ fintechnews.sg/1302/fintech/sesame-credit-data-driven-credit-scoring/ (30.12.2018).

Shadbolt, N.R. (2013), Knowledge acquisition and the rise of social machines, "International Journal of Human-Computer Studies" 71(2): 200-205. 
Smart, P.R., N.R. Shadbolt (2014), "Social Machines.", [w:] M. Khosrow-Pour (red.), Encyclopedia of Information Science and Technology, (Hershey: IGI Global): 6855-6862.

Stawska, K. (2021), Internet, jakiego nie znamy, dzięi 6G. Padła data, https:/ / tech.wp.pl/ internet-jakiego-nie-znamy-dzieki-6g-padla-data-6614763926350464a (5.03.2021).

Strittmatter, K. (2020), Chiny 5.0. Jak powstaje cyfrowa dyktatura, (Warszawa: Wydawnictwo W.A.B.).

Sumpter, D. (2019), Osaczeni przez l1cz3y. O algorytmach, które kontrolują nasze życie. Od Facebooka i Google'a po fake newsy i bańki filtrujace, (Kraków: Copernicus Center Press).

Walewski, Ł. (2020),Wł@dza w sieci. Jak nami rządza social media, (Kraków: Mando).

Webb, A. (2019), The Big Nine. How the Tech Titans and Their Thinking Machines Could Warp Humanity, (New York: PublicAffairs).

Wellman, B. (2001), Physical Place and Cyberplace. The Rise of Personalized Networking, "International Journal for Urban and Regional Research", 25(2): 227-252.

$\mathrm{Wu}, \mathrm{T}$. (2010), The Master Switch. The Rise and Fall of Information Empires. New York: Alfred A. Knopf). 
